\title{
Possible effect of decreased insulin resistance on ferritin levels after Nordic Walking training
}

This article was published in the following Dove Press journal:

Clinical Interventions in Aging

16 February 2016

Number of times this article has been viewed

\author{
Birkan Ilhan \\ Fatih Tufan \\ Gulistan Bahat \\ Mehmet Akif Karan \\ Department of Geriatrics, Istanbul \\ School of Medicine, Istanbul \\ University, Istanbul, Turkey
}

Correspondence: Fatih Tufan

Department of Geriatrics, Istanbul School of Medicine, Istanbul University, PO Box 34093, Sehremini, Fatih, Istanbul, Turkey Tel $+90212414 I 500$

$\mathrm{Fax}+902124142022$

Email fatihtufan@gmail.com

\section{Dear editor}

We read with interest the article by Kortas et al ${ }^{1}$ entitled "Effect of Nordic Walking training on iron metabolism in elderly women." In their study, the authors investigated the effect of Nordic Walking (NW) training on serum ferritin, C-reactive protein (CRP), hepcidin, hemojuvelin, and vitamin $\mathrm{D}$, which have been stated as components of the inflammatory system. In this study, while NW training significantly reduced iron stores and increased hemojuvelin and tended to reduce CRP levels, it did not affect hepcidin levels. The authors also observed a significant weight loss after training. The authors concluded NW training has pro-healthy effects manifested by decreased inflammation and a drop in iron stores.

It is well known that obesity is associated with insulin resistance and physical exercise and weight loss reduce insulin resistance. Several studies indicate a positive correlation between iron levels and insulin resistance. ${ }^{2,3}$ There is also a relationship between insulin resistance and CRP levels. ${ }^{4}$ The possibility of decreased insulin resistance with weight loss after training can also contribute to the decline in CRP and ferritin levels in this study. The authors mentioned that they did not observe the anticipated increase in hepcidin levels after exercise. As the authors stated, hepcidin levels increase in response to both inflammation and exercise. Because the mean body mass index of the study population is in the overweight range, these subjects might have insulin resistance and associated inflammation. Thus, the anticipated increase in hepcidin levels with exercise might have been attenuated via decreased inflammation in this study. This two-way interaction may account for the unchanged hepcidin levels. The authors did not report insulin levels in this study and did not discuss the probable effect of insulin resistance on the relationship between ferritin and exercise. We suggest that consideration of these factors may facilitate interpretation of the findings of this study. We also suggest that insulin resistance would better be assessed in future studies in this field.

\section{Disclosure}

The authors report no conflict of interest in this communication.

\section{References}

1. Kortas J, Prusik K, Flis D, et al. Effect of Nordic Walking training on iron metabolism in elderly women. Clin Interv Aging. 2015;10:1889-1896.

2. Zafar U, Qureshi HJ, Imran M. Comparison of iron status and insulin resistance between non-diabetic offsprings of type 2 diabetics and non-diabetics. J Ayub Med Coll Abbottabad. 2015;27(2):307-311.

3. Bonfils L, Ellervik C, Friedrich N, et al. Fasting serum levels of ferritin are associated with impaired pancreatic beta cell function and decreased insulin sensitivity: a population-based study. Diabetologia. 2015;58(3):523-533.

4. Ndumele CE, Pradhan AD, Ridker PM. Interrelationships between inflammation, C-reactive protein, and insulin resistance. J Cardiometab Syndr. 2006;1(3):190-196. 


\section{Authors' reply}

Jakub Kortas'

Katarzyna Prusik ${ }^{2}$

Damian Flis ${ }^{3}$

Krzysztof Prusik'

Ewa Ziemann ${ }^{4}$

Neil Leaver ${ }^{5}$

Jedrzej Antosiewicz ${ }^{6}$

'Department of Recreation and Tourism, ${ }^{2}$ Department of Biomedical Basis of Health, Gdansk University of Physical Education and Sport, ${ }^{3}$ Department of Bioenergetics and Physiology of Exercise, Medical University of Gdansk, ${ }^{4}$ Department of Physiology and Pharmacology, Gdansk University of Physical Education and Sport, Gdansk, Poland; ${ }^{5}$ The IMS Laboratory, Royal Brompton \& Harefield NHS Foundation Trust, Heart Science Centre, Harefield Hospital, Harefield, UK; ${ }^{6}$ Department of Biochemistry, Gdansk University of Physical Education and Sport, Gdansk, Poland

Correspondence: Jedrzej Antosiewicz

Department of Biochemistry, Gdansk University of Physical Education and Sport, Kazimierza Górskiego I, 80-336 Gdańsk, Poland

$\mathrm{Tel}+48585547325$

Fax +4858552075I

Email jant@gumed.edu.pl

\section{Dear editor}

We are really pleased to hear that you are interested in our article and we believe that a very important issue has been raised. It is suggested that the effects of lack of exercise on blood hepcidin may be due to reduced inflammation and increased insulin sensitivity. In our opinion, there are studies which do and do not support this suggestion. There is evidence for a positive correlation between body iron stores and insulin resistance. However, there are two important questions to be answered: 1) Can accumulated iron be responsible for induction of insulin resistance? 2) Can impairment of insulin signaling lead to iron accumulation? There is some evidence that the answers to these questions are positive. For example, reduction of body iron stores by phlebotomy leads to an increased insulin sensitivity. ${ }^{1}$ Our observation is that a decrease in body iron stores after the training should be considered a positive change and we agree that it would be interesting to associate these data with parameters of glucose metabolism. In addition, elevated hepcidin concentrations and the association between diabetes and obesity with ferritin and CRP levels were observed. ${ }^{2}$ Which supports the claim. Conversely, there is evidence that insulin can depress hepcidin biosynthesis. ${ }^{3}$ And insulin resistance is associated with low blood hepcidin levels in diabetics. ${ }^{4}$ This might explain why there is iron accumulation in type 2 diabetic patients. The reason for these results is difficult to speculate. Anti-inflammatory effects of exercise are well documented. ${ }^{5}$ In fact, we observed some decrease in CRP concentration after 32 weeks of training, but it is too early to speculate if this was responsible for the observed changes in iron metabolism. We checked the correlation between weight and body mass index versus CRP, hepcidin, hemojuvelin, and ferritin. We found out that only correlation between the level of ferritin and weight was significant (at baseline: $r=0.46, P=0.01$; after training: $r=0.47 ; P=0.01$ ). It is important to note that there were training-induced increases in hepcidin in 16 of our subjects, whereas in the remaining 21 a decrease was observed. The reason for this differing response to exercise is not clear to us. Thus, we should consider that other factors may be involved. In summary, we agree that the effects of exercise on iron metabolism can be mediated by changes in insulin sensitivity and some modification of inflammation. We would like to thank Ilhan et al for their valuable suggestions, which will all be addressed in our forthcoming project.

\section{Acknowledgment}

This investigation was supported by the National Science Centre (Poland), project no 2014/15/B/NZ7/00976.

\section{Disclosure}

The authors report no conflict of interest in this communication.

\section{References}

1. Fernandez-Real JM, Penarroja G, Castro A, Garcia-Bragado F, Hernandez-Aguado I, Ricart W. Blood letting in high-ferritin type 2 diabetes: effects on insulin sensitivity and beta-cell function. Diabetes. 2002; 51(4):1000-1004.

2. Andrews M, Soto N, Arredondo-Olguin M. Association between ferritin and hepcidin levels and inflammatory status in patients with type 2 diabetes mellitus and obesity. Nutrition. 2015;31(1):51-57.

3. Wang H, Li H, Jiang X, Shi W, Shen Z, Li M. Hepcidin is directly regulated by insulin and plays an important role in iron overload in streptozotocin-induced diabetic rats. Diabetes. 2014;63(5):1506-1518.

4. Sam AH, Busbridge M, Amin A, et al. Hepcidin levels in diabetes mellitus and polycystic ovary syndrome. Diabet Med. 2013;30(12):1495-1499.

5. Dulian K, Laskowski R, Grzywacz T, et al. The whole body cryostimulation modifies irisin concentration and reduces inflammation in middle aged, obese men. Cryobiology. 2015;71(3):398-404. 
Dove Medical Press encourages responsible, free and frank academic debate. The content of the Clinical Interventions in Aging 'letters to the editor' section does not necessarily represent the views of Dove Medical Press, its officers, agents, employees, related entities or the Clinical Interventions in Aging editors. While all reasonable steps have been taken to confirm the content of each letter, Dove Medical Press accepts no liability in respect of the content of any letter, nor is it responsible for the content and accuracy of any letter to the editor.

Clinical Interventions in Aging

\section{Publish your work in this journal}

Clinical Interventions in Aging is an international, peer-reviewed journal focusing on evidence-based reports on the value or lack thereof of treatments intended to prevent or delay the onset of maladaptive correlates of aging in human beings. This journal is indexed on PubMed Central, MedLine,

Scopus and the Elsevier Bibliographic databases. The manuscrip management system is completely online and includes a very quick and fair peer-review system, which is all easy to use. Visit http://www.dovepress. com/testimonials.php to read real quotes from published authors.

Submit your manuscript here: http://www.dovepress.com/clinical-interventions-in-aging-journal 